\title{
4. Social stigmatisation, cultural coercion, and peer- pressure faced by Pacific student reporters A Wansolwara student press case study in
problem-based learning
}

Abstract: This set of three case studies, with elements of problem-based learning, examines how University of the South Pacific (USP) journalism students deal with social pressure applied by their peers, and the impact on learning. This is becoming an urgent and increasing concern due to the new, global realities of trolling and cyber bullying. This article is part of ongoing research into applied learning and teaching through the USP journalism student training newspaper, Wansolwara. The first case study deals with social stigmatisation, the second with intimidation, and the third with assault and cyber bullying. This article argues that social pressures are both a threat and an opportunity. As unpleasant as the hostile reactions are, they are a reality of practising journalism. Student reporters' exposure to such confronting situations provides an early taste of real world journalism. The learning outcomes show that the experience toughens students' resolve. For those bearing the brunt of the vitriol, coping mechanisms such as guidance by lecturers, support from fellow journalism students, family encouragement, and due recognition of their journalistic work, are critical. This article contends that unlike physical harm, psychological harm to student journalists is overlooked. This trend is risky, especially in the digital media age, and needs to be addressed.

Keywords: culture, cyber bullying, Fiji, Pacific Islands, problem-based learning, social pressure, trolling, USP Journalism Programme

\section{SHAILENDRA SINGH and ELIKI DRUGUNALEVU \\ University of the South Pacific}

\section{Introduction}

EARNING by doing, or problem-based learning (PBL), is considered a vital element of journalism training, and forms an integral part of the curricula at many journalism schools. At the University of the South Pacific 
(USP) in Suva, Fiji, the multiple Ossie Award-winning student training newspaper Wansolwara has been a crucial component of journalism education for 20 years. Through the newspaper, students get their first real taste of establishing and building contacts, organising and conducting interviews, attending and reporting press conferences, writing news and features to deadline, and managing the editorial and production processes. The cost-benefit analysis of PBL has been much discussed. With regards to Wansolwara, previous papers looked at first-hand student experiences in circumventing gatekeeping at USP and skirting state censorship in covering the 2000 and 2006 Fiji coups. The exposure instilled problem-solving skills (Drugunalevu \& Manarae, 2015; Robie, 2001; 2010).

This article seeks to determine the kinds of social pressures student reporters faced while covering news for Wansolwara and how they coped. As a melting pot of students and staff from 12-member Pacific Island countries (and beyond), USP's Laucala campus is a microcosm of the Pacific region. Pacific journalists face certain cultural, social and political barriers in trying to apply media's Fourth Estate principles in their localities. This includes harassment and violence from local politicians and their functionaries (Robie, 2002a; 2010; Smiles, 2001). Among other things, this study tries to establish whether student journalists are similarly affected in their coverage of USP student affairs and if there was any psychological impact.

\section{The literature}

This article is part of ongoing research into applied learning/teaching through the USP student press, Wansolwara. Previous papers looked at the institutional challenges of covering the Fiji coups and dealing with Fiji's punitive media decrees (Drugunalevu \& Manarae, 2015; Robie 2001, 2010; Singh, 2010). This student-centred teaching approach has elements of 'problem-based learning'. This is an 'active, integrated and constructive' technique influenced by social and contextual factors (Barrows, 1996; Wilkerson \& Gijselaers, 1996). Students recognise problems as 'professionally relevant' and they are subsequently 'more likely to be motivated' to work on them (as opposed to textbook exercises). The inspiration comes not only because students realise that the knowledge they gain will be useful, but also because students are typically given 'significant opportunities for creativity and flexibility' (Speaking of teaching, 2001, p. 2).

Journalism educators believe PBL allows students to 'skill-up quickly' and spend more time 'actually applying these skills to real life situations - and learning far more effectively in the process' (Meadows, 1997, p. 102). According to Robie (2012), teaching and learning based on the 'real world' of structured problems faced by newsroom professionals is a highly appropriate framework 
for journalism school publishing. Hartnett (2010) too has emphasised the efficacy of the PBL methodology in a publishing context, noting that it enables media to become 'enmeshed to its very core in the larger promises of democratic governance, enlightenment principles and civic life' (p. 71). However, there are some potential traps, such as the tendency to mirror deadline-driven professional newsroom practices, rather than encourage a more critical framework. As a safeguard, PBL should go beyond the narrow realm of the reporter in a reconstructed newsroom by strengthening links with the academy to develop critical thinking (Meadows, 1997).

Through PBL, USP students learnt to deal with institutional pressure and state censorship, which has received some coverage. However, data on the impact of social pressure, especially from their peers, is lacking. Internationally, there is considerable knowledge about the traumas of reporting war, conflict, natural disasters, horrific accidents, sex crimes, and post-traumatic stress disorder (see Dart Center for Journalists: http://dartcenter.org/classroom-resources). Researchers such as Wake (2016) have queried what media educators are doing to train students for future reporting assignments in foreign conflict zones, particularly as underprepared freelance journalists lining up for assignments in trouble spots, with the prospect of dying on the job. Wake argues that the increased risks in deadly conflict zones makes it incumbent upon media educators to ensure that students are better prepared to undertake such jaunts after they graduate.

In the face of the potentially lethal dangers on overseas assignments, reporting on home soil, including the university environment, can appear benign. As such, the physical and emotional risks on local beats can be overlooked. This is underscored by the apparent scarcity of information on the kinds of pressures student reporters encounter on their 'regular' rounds and how such pressures might affect them. This gap needs to be addressed, especially given the peculiarities of practising journalism in the Pacific cultural and political contexts. As Robie writes:

Customary obligations and pressures are frequently a burden on journalists in the South Pacific. Such obstacles create difficulties for many journalists. Often it takes raw courage to be a neophyte journalist in the Pacific. (Robie, 2002b, p. 147)

Culture is an important variable in the Pacific. It is the source of family and community power, to the point that anyone who defies certain cultural norms can be cast aside (Masoe \& Prescott, 2011). This research involves a case in which a Samoan student reporter was accused of breaching the fa'asamoa, or the Samoan way. Fa'asamoa binds on the basis of shared values and beliefs, and is considered the embodiment of Samoan culture (Tuafuti, 2011; Swain, 
1999). Fa'asamoa even weighs on the national media, which is expected to play an important role in fostering a sense of national culture and collective national identity through the exclusion or inclusion of others (Matthews, et. al., 2008; Kenix, 2015).

If cultural constraints are an old problem, social media is a new one. Hinduja and Patching (2007) write that a proliferation of chat rooms, online forums, and social media platforms have become a 'communal breeding ground' for users to verbally assault one another. This is cyber bullying, which constitutes repeated harm inflicted through the use of computers, cell phones, and other electronic devices to post humiliating information about someone in an online public forum (Hinduja \& Patching, 2007). Trolling, closely associated with cyber bullying, involves individuals posting false information intended to hurt and/or antagonise their victims (Buckels, et. al. 2014). Cyber bulling and trolling thrive on the anonymity offered by the internet (Klempka \& Stimson, 2014).

A handful of papers on troll attacks on student journalists were presented at the Fourth World Journalism Education Congress (WJEC) in Auckland in mid2016. Wolfe (2016) looked at the damaging impact of trolling on new journalists. Wolfe's work was inspired by the realisation that the massive growth in cyber bullying had not been 'paralleled by the development of help and guidance for those involved in journalism'. Social media has not only increased the likelihood of cyber bullying, it has also enlarged its scope and magnitude, given the infiniteness of cyberspace. Wolfe's interviews with graduates and undergraduates found them encountering difficulties in handling negativity online. Some cases were 'quite shocking' and underscored the need to know how to deal with comments 'before they occurred, rather than afterwards, while reeling from the assault'. Her study found that 'acid-tongued' trolls had even managed to stifle online discussion in the case of Popular Science magazine, which scrapped its comments section, with the warning that 'lively, intellectual debate' and the ability to inform the public about science issues were 'under threat'. Wolfe's work not only highlights the risk to student journalists on cyberspace, but also the need to quickly recognise the threat and deal with it preemptively.

The Wansolwara experience shows that the intimidation and harassment of journalism students is neither new, nor is it confined to cyberspace. Insofar as Wansolwara is concerned, the phenomenon is nearly as old as the 20-year-old newspaper itself. New Zealand-based media academic Philip Cass (2016), the founding lecturer of Wansolwara, has highlighted how early in the paper's history, the coverage of some financial irregularities within the USP Student Association led to threats against student reporters.

\section{Methodology}

This study used non-probability purposive sampling, whereby the researcher 
uses personal judgment to select case studies to help answer the research questions or achieve the research objectives (Black, 2010). The mixed purpose approach combines one or more purposive sampling techniques (Babbie, 2010). In this study we pooled three inter-related procedures: critical case sampling, which focuses on specific dramatic or important cases; intensity method, which selects a small number of excellent examples of the phenomenon of interest (but not extreme cases) based on prior knowledge; and critical case selection, which picks samples likely to yield the most information, or have the greatest impact.

This study's lead researcher has been teaching the print and online journalism course at University of the South Pacific since 2001. The associate researcher is a USP Journalism alumni, now a teaching assistant with the programme. We used prior knowledge and experience to systematically identify three news stories with information-rich narratives to be used as case studies. The articles - published in 2001, 2005 and 2015 - dealt with the low pass rate of USP's Samoan students and the misuse of USP Student Association finances. These cases stood out because of the backlash they attracted when initially published. The story selection was guided by the literature on qualitative methodologies, which recommends small samples that provide key insights into the issues being explored. Size doesn't matter: As Patton (2002) asserts, the reliability and value of qualitative research is often enhanced by the information richness of the cases rather than the size of the sample.

After the stories were identified, the authors were contacted and informed about the study's goals, purpose and methods. All three agreed to participate and go on the record, with the option of withdrawing, without prejudice, at any time of their choosing. The interviews were conducted by phone, email and in person. The interview questions centred on the themes derived from the literature. They included:

- Did you expect the reactions that your story received?

- How well did the course prepare you for the stresses, and what more could be done?

- What were the psychological impacts of the negative reactions?

- How were your studies affected?

- What about your attitude towards journalism as a future career?

- Any long term impact and learning outcomes.

The data analysis drew insights from Braun and Clarke's (2006) six steps of thematic analysis, which involves close reading and understanding of the data, and identifying and analysing the themes and patterns that emerge. With regards to limitations, the first two interviewees had left the university when the interviews took place. The third interviewee was still a student. This blend yielded a good mix of reflective and current viewpoints. 


\section{Case Study One-Samoa Probes Study Slump}

Case Study One involved the ostracism of Misa Vicky Lepou, then a final year Samoan student, over a page one lead story entitled Samoa Probes Study Slump published in September 2001. The story was about the Samoan government and New Zealand Aid investigating a dramatic slump in first year students' academic performance by up to 70 percent. The reasons cited included disruptions caused by Fiji's 2000 coup, excessive socialising, and homesickness. The story quoted prominent Samoans making appeals to the students to study harder.

According to Misa, the story was negatively received by the Samoan student body as it was deemed insulting (M. V. Lepou, personal communication, 6 June 2016). Misa's actions were seen to have breached Samoan solidarity, based on the cultural concept of fa'asamoa, which means the Samoan way. Fa'asamoa requires individuals to act in the best interest of the wider community rather than individual interests (Masoe \& Prescott, 2011; Raby \& Tarrow, 2013). Misa had some premonition about the negative reaction, but she was not wholly prepared for the full extent of the backlash, which included being shunned and excluded from the Samoan student community. She was brought to tears by a particularly harsh reaction from a fellow Samoan student. Her parents came to mind, and she started questioning herself. Her studies were affected, and for a short while, she felt like giving up journalism. Misa stated:

I was emotionally depressed. I tried so much to keep myself together and think things over; whether I did the right thing or not given the impact of the story on our community. (Lepou, personal communication, 6 June 2016)

With regards to coping mechanisms, Misa said support of journalism staff and fellow students was crucial. Studying about the challenges Pacific Island journalists faced helped prepare her for the coming ordeal. The journalistic work of her lecturer, David Robie, was an inspiration:

The intense programme exposed me to a lot of case studies that featured far worse risks regional and international journalists faced. Seeing David Robie's work and how he has been behind us all was something to be proud of. (Lepou, personal communication, 6 June 2016)

Family support was also vital. When the story reached Samoa, Misa's father indicated that he was proud of her work. Misa stated: 'Your family of course will always be the first behind you' (Lepou, personal communication, 6 June 2016). With regards to learning outcomes, Misa indicated that the experience made her 'thick-skinned'. She realised that negative reactions to some stories were inevitable. She was willing to endure the consequences if the story led to positive outcomes. 
I thought that if this story is going to have an impact (politically) on my education, I would endure the consequences. But it will not change who I am if it's my calling to be a journalist. (Lepou, personal communication, 6 June 2016)

On how well the journalism course prepared her to face such forms of social pressure, Misa stated that the emphasis on journalistic independence and the importance of the watchdog role were quite relevant. On what could be done to better prepare students, Misa recommended more mentoring and forewarning about the possible consequences of certain stories.

\section{Case Study Two-Audit Shock}

Case Study Two involved threats and coercion against second year student Erica Lee, for a page one lead story entitled, Audit Shock, published in September 2005. The story highlighted an audit report showing a FJ\$90,000 discrepancy in the USP Student Association finances. This included 'fictitious' expenditure that might never be recovered. The student president and treasurer refused comment. There were allegations of personal purchases, including a car. A separate committee had been formed to look into the matter. Police had also been called in.

The student executives disputed the facts in the story. Lee faced a menacing response, with three student executives warning her that 'something would happen' if she did not retract the story. On another occasion, one executive drove his car towards her in an intimidating manner while she was crossing outside USP (E. Lee, personal communication, 15 June 2016). The executives in question hurled abuse at Lee when they came across her on campus. Lee had a suspicion there would be a backlash:

Yes, I was prepared. My lecturer Shailendra was a great mentor and he had helped me with the initial story structure and told me about what I might expect after publishing the story. (Lee, personal communication, 15 June 2016)

For several weeks, Lee was constantly looking over her shoulder, which affected her movement (Lee, personal communication, 15 June 2016). However, in time, Lee not only overcame her initial apprehensions, she felt that she had become a better student as a result of the experience. She developed a stronger interest in reporting and started writing more articles for Wansolwara. Regarding learning outcomes, Lee stated that she became familiar with some of the practicalities of financial procedures and developed a keenness for investigative journalism:

....as time passed, I thought that what I was doing was right. I received a lot of great feedback. It also helped me to refocus as a student because in my first year, I didn't really put in a lot of effort. I became interested in 
investigative journalism. That was probably part of the reason why I joined the anti-corruption commission as a public affairs officer. (Lee, personal communication, 15 June 2016)

In terms of coping mechanisms, the USP Journalism Students Association (JSA) was quite crucial. Three senior male journalism students chaperoned her around campus. The guidance, support, and mentoring from the lecturers also helped. She felt that the experience hardened her resolve. Lee was further buoyed by winning an award at the annual USP Journalism awards.

I received a lot of great feedback on the story. Being recognised with two awards for those investigative pieces really made me feel proud. Even though there were weeks of fear, I overcame that. The network and support that JSA provides is great. (Lee, personal communication, 15 June 2016)

On how well the course prepared her to handle such pressures, Lee stated that the lecturers had informed her about what to expect. On what could be done to better prepare students, Lee felt that a thorough briefing about the risks would be useful, as well as guidelines on how to respond to aggressive reactions, including clear instructions about who to call, and the formation of peer support networks (Lee, personal communication, 15 June 2016).

\section{Case Study Three-Five Years, Zero Audits}

In Case Study Three, the line between intimidation and violence was crossed, and cyber bullying emerged as a new threat. It was in reaction to another page one story titled, Five Years, Zero Audits, published in April 2015. Written by second year student Shalveer Singh, the story revealed that the student body had failed to produce audited accounts for five consecutive years since 2009 . The USP Student Federal chair Whitlam Saeni blamed the failure to audit on inadequate funding, although the 2013 annual income was nearly FJ\$214,000. Asked whether the student association was transparent, acting president Andrew Semeli replied: '50/50'.

Shortly after the story was published, Saeni, a Solomon Islander, disputed some facts, and stated that he had not given permission to have his photo taken during the interview. Saeni assaulted Singh on campus (USP probe over student chief attack, 2015). Singh, who was shaken but unhurt, also faced cyber bullying. On whether he had anticipated such a reaction, Singh said that he had learnt how journalists were sometimes treated badly. He was ready to take risks in future, but did not expect problems in his second year of studies. Cyber bullying came as a complete surprise (S. Singh, personal communication, 25 June 2016). In Singh's case, the online comments were posted on the Solomon Island Students Association Facebook page. One comment described Singh as 'gay' while another 
said that Saeni should have punched Singh 'harder'.

Initially, Singh was quite disheartened, but he recovered. In terms of the impact on his education, the incident did not change his views about studying or practising journalism. Regarding coping mechanisms, the support of fellow students and mentoring by the lecturers was a boost (Singh, personal communication, 25 June 2016).

Winning an award at the annual USP Journalism prize-giving was further inspiration. In terms of learning outcomes, Singh realised the value of thoroughly researching the subject matter and asking tough questions. He also learnt lessons beyond journalism, such as dealing with USP administration in relation to his case and following things through. He was encouraged to see the USP Student Association make positive changes as a result of his story. Reflected Singh:

I realised this was my chosen career so I have to cope with incidents psychologically. Seeing the student association start to audit their reports properly was empowering. (Singh, personal communication, 25 June 2016)

On how well the course prepared students to face such pressures, Singh said he did not anticipate being assaulted or cyber bullied because these sorts of actions by student leaders were unexpected. Singh believes journalism students should be briefed in their first year about what to do if caught in this type of situation. He felt that the revival of the JSA was really important.

\section{Discussion of the findings and USP journalism responses}

In this section, we collate, group and analyse related themes, and discuss USP Journalism's responses.

On how well the course prepared students for the pressures and what more could be done:

In all three case studies, the student reporters had only some inclination about what was in store. They felt that they could have been better prepared with more forewarning. Misa Vicky Lepou was caught unawares by her fellow Samoans' chilly reception and hostility; Erica Lee did not expect the thuggish behaviour she encountered; and Shalveer Singh was surprised by his assault and the cyber bullying. Class discussions, case studies of journalist repression in the Pacific as well as briefings and prior warnings by the lecturers helped. Students suggested that briefings could be more thorough, specific with greater emphasis on how to respond to and cope with both aggressive and non-aggressive reactions.

USP Journalism response: Staff briefed students about the potentially negative fallouts, but to some extent, they too were caught unawares, partly because the specifics and full extent of what unfolds after a story is published cannot always be anticipated, and partly because the students did not fully inform staff 
about the seriousness of the developments. In PBL, teachers act as facilitators rather than disseminators (Barrows, 1996), but this study indicates that, even while merely facilitating, the lecturers still need to work closely with students, especially on potentially troublesome stories. This has to happen throughout the course of the assignment to better anticipate potential outcomes and strategise how to respond to specific cases. Course outlines focus more on how to cover and write stories, and far less on how to respond to the fallout. This imbalance needs to be addressed, particularly in the internet age, as Wolfe's (2016) pioneering work indicates.

Lecturers also need to keep students fully updated about any and all negative reactions to a story as often, students are not forthcoming about harassment issues. The lead author knew about some of the issues associated with the case studies used, but only became fully aware of what the students had to endure after conducting this research. The findings highlight the need for tutorials and workshops on forms of social pressure students could face. This research, and others about the challenges faced by Wansolwara reporters (Drugunalevu \& Manarae, 2015), could be introduced into teaching.

On the emotional impact of the negative reactions, effect on studies, and coping mechanisms:

For a short while, students experienced fear, hurt, depression, sadness, selfdoubt, anger, and disheartenment. At least one student said she felt like giving up journalism. For Misa Vicky Lepou, allegations that her story dishonoured fa'asamoa cut deep. Because Samoan society encourages individuals to identify themselves as part of the extended community (Masoe \& Prescott, 2011; Raby \& Tarrow, 2013), portraying Misa as an outsider from within was an effective way of making her feel isolated from her closely-knit campus community. For her and the two other student reporters, the coping mechanisms included staff, student and family support, positive feedback received on stories, and being recognised at the awards night.

USP Journalism response: This research was a revelation of sorts with respect to the emotional turmoil experienced by students. Misa Vicky Lepou's case study highlighted the clash between media's liberally-oriented Fourth Estate role applied by Pacific journalists, and some Pacific cultural norms based on group rights and respect for authority (Kenix, 2015; Tupuola, 1994). This is a tension whose effects on young student journalists needs to be monitored and addressed.

This study's findings could have international ramifications in terms of coping mechanisms to deal with the emotional stress students encounter in the line of duty, especially given the growing risk of trolling globally (Wolfe, 2016). This research showed that positive feedback on stories and recognition of journalistic endeavour countered the negativity. Another boost was support from fellow journalism students. These findings vindicated USP Journalism's 
move to encourage the revival of the JSA and the awards ceremony. In 2016, the JSA reported to USP authorities alleged harassment of a student journalist by a USP staff member while on assignment. The JSA lodged the complaint jointly with the USP Students Association (the irony is worth noting). In June 2016 the JSA also issued a media statement in support of the striking University of Papua New Guinea students (USP students condemn 'highly reckless' police, 2016). The JSA president Shalveer Singh urged the authorities to exercise restraint, criticised the police for their 'recklessness' and described the PNG students as our 'brothers and sisters' (USP students condemn, 2016). This example shows that journalism student associations can be an integral 'part' of PBL. Besides camaraderie with victimised students, such associations play a part in increasing students involvement in democratic governance and civic life. In the case of JSA, such consciousness transcend their own university and national borders. Hartnett (2010) has highlighted such outcomes of PBL in journalism.

Based on the findings, USP Journalism has taken steps to encourage the JSA to expand and solidify its networks to include media advocacy groups such as the Pacific Freedom Forum, the Fiji Media Association, and the Pacific Media Centre, based at the Auckland University of Technology. USP journalism students are members of the Fiji Media Association and participate in its activities. Other coping mechanisms include the USP counselling centre at the Laucala Campus. The centre provides free, confidential professional services to both students and staff. USP Journalism has resolved to be more alert and report the more serious cases to the police.

\section{Long-term impact on student journalists and learning outcomes}

As previously discussed, the despondency felt by the affected students was temporary, and any thoughts about dropping out of the journalism course were fleeting, with all completing their programmes. In all three cases, the students emerged stronger from the experience. One student stated, it 'made me thickskinned' while another found it 'empowering'. This is evidence of preparation for the future challenges of practising journalism as professionals (Robie, 2012). For example, Singh was motivated to do more investigative stories (his next major assignment in 2016 looked at the increasing availability of hard drugs in Fiji). The case studies showed that through applied journalism, students who had been coasting through their coursework began to take their studies more seriously. This illustrates increased student motivation driven by working on real-life, professionally-relevant problems, a strong feature of PBS (Speaking of teaching, 2001, p. 2).

USP Journalism response: The PBL approach offered early lessons on how to deal with negativity, threats and harassment. Unpleasant as such hostile reactions were, they were not entirely unwelcome. The case studies show that learning to 
cope with antagonism builds student resolve, which cannot be fully achieved in the classroom alone. The case studies reinforce the idea of encouraging student journalists to tackle difficult story assignments rather than avoid them. That the students did not experience any long-term effects as a result of their negative experiences does not negate the need for the establishment of strong support systems. Not all students would be as hardy as those in the case studies, who were assigned the difficult stories in the first place because of their leadership potential. The case studies represent just one incident, from which recovery was fairly swift. In the real world, the pressures will likely be much higher and more frequent, particularly in the Pacific context (see Smiles, 2001).

\section{Conclusion}

This research analysed how USP student journalists coped with intimidation, cultural coercion and assault from their peers while on the beat. The study followed previous ones on how students tackled institutional pressures, and the learning outcomes, such as developing new problem-solving skills in real life situations (Drugunalevu \& Manarae, 2015). This latest paper, focused on social pressure, indicated that student journalists developed resilience and fortitude, and a deeper appreciation of the media's watchdog role. The experiences were deemed as good preparation for life as a professional journalist in the Pacific context.

The outcomes reiterate the efficacy of the PBL approach in journalism education and strengthen the findings of previous studies on the subject matter (Robie, 2012). The study reinforces the idea that students should not be cocooned because they learn from exposure to confronting situations. However, if students are going to be exposed to antagonising situations, then it is incumbent upon journalism educators to better understand and deal with the potential psychological hazards. So far the emphasis seems to have been on physical hazards (Dart Centre, n.d; Wake, 2016), which implies that they are considered more important than psychological hazards. This attitude is being challenged in the internet age and proliferation of social media, which pose new and magnified threats. Even students covering the supposedly benign campus beats are not immune to cyber bullying and trolling (see Wolfe, 2016). These forms of pressure are not to be underestimated as they can be psychologically and emotionally damaging, especially for youth, even driving them to the point of attempting suicide (Hinduja \& Patching, 2007), more so in the trolling environment.

The case studies showed that the under-pressure student reporters thrived on the support received from fellow students, teaching staff and family members. This support network played an important part in helping students shake off the negativity and carry on with the journalistic work with renewed zeal. Students also received succour from the journalism student body, the USP students association, professional journalists association and regional media advocacy 
groups. University journalism programmes might want to consider supporting the establishment of similar networks: As Wolfe (2016) has pointed out, students will need support to deal with the new troll environment. Otherwise, they may avoid encounters and self-censor. Wolfe's assertions show that social pressures can affect the very core of journalism, and need to be taken seriously as part of learning and teaching.

\section{References}

Andersen, M. L., Taylor, H. F. \& Logio, K. A. (2015). Sociology: The essentials (9th Ed.). Cengage Learning, Boston, USA.

Babbie, E. (2010). The practice of social research (13th Ed.). Belmont, CA: Thomson Wadsworth Publishing.

Barrows, H. S. (1996). Problem-based learning in medicine and beyond: A brief overview. In L. Wilkerson \& W. H. Gijselaers (Eds), Bringing Problem-Based Learning to Higher Education: Theory and Practice (pp. 3-12). San Francisco: Jossey-Bass. Cass, P. (1999).

Black, K. (2010). Business statistics: Contemporary decision making (6 ${ }^{\text {th }}$ Ed.). Hoboken, NJ: John Wiley \& Sons.

Braun, V., \& Clarke, V. (2006). Using thematic analysis in psychology. Qualitative Research in Psychology, 3, 77-101.

Buckels, E. E., Trapnell, P. D., \& Paulhus, D. L. (2014). Trolls just want to have fun. Personality and Individual Differences, 67, 97-102.

Cass, P. (2016, July). The ghost of Felix Culpa. Paper presented at the 4th World Journalism Educators Congress (WJEC) Pre-conference on Journalism Education in the Pacific. Auckland University of Technology, New Zealand.

Dart Center for Journalism \& Trauma (n.d). Classroom resources. Columbia Journalism School. Retrieved on November 30, 2016 from http://dartcenter.org/classroomresources.

Drugunalevu, E., \& Manarae, I. (2015). Media freedom in Fiji: Journalism challenges facing Wansolwara, an independent, campus-based newspaper. Pacific Journalism Review, Political Journalism in the Asia-Pacific, 20 Years Special Edition, 21(1), 151-163.

Hartnett, S. J. (2010). Communication, social justice and joyful commitment. Western Journal of Communication, 74(1), 68-93.

Hinduja, S. \& Patchin, J. W. (2007). Offline consequences of online victimization: School violence and delinquency. Journal of School Violence, 6(3), 89-112.

Kenix, L. J. (2015). You are either with us or with us: Constructing a Samoan national identity through inclusion at the Samoa Observer. Journalism, 16(4), 553-570.

Klempka, A., \& Stimson, A. (2014). Anonymous communication on the internet and trolling. Concordia Journal of Communication Research, Concordia University Saint Paul. Retrieved on November 28, 2016 from: https://comjournal.csp.edu/wp-content/ uploads/sites/16/2013/12/TrollingPaper-Allison-Klempka.pdf

Masoe, A. C., \& Prescott, S. (2011). The development of accounting in Samoa: The long and winding road. Paper presented at the Samoa Conference II: Tracing Footprints of Tomorrow: Past Lessons, Present Stories, Future Lives. Apia, National University of Samoa, Samoa.

Matthews, G., Ma, Kit-wai, M., \& Tai-Lok, L. (2008). Hong Kong, China: Learning to belong to a nation. New York, NY: Routledge Publishing. 
Meadows, M. (1997). Taking a problem-based learning approach to journalism education. Asia Pacific Media Educator, 3, 89-107.

Patton, M. Q. (2002). Qualitative research and evaluation methods (3rd ed.). In Raby, R. S. \& Tarrow, N. (Eds.). (2013). Dimensions of the community college: International, intercultural, and multicultural perspectives. New York, NY: Routledge.

Robie, D. (2001). Coup coup land: The press and the putsch in Fiji. Asia Pacific Media Educator, 10, 148-62.

Robie, D. (2002a). Cyberspace news on campus: The South Pacific experience, Asia Pacific Media Educator, 12, 203-219. Retrieved from http://ro.uow.edu.au/apme/ voll/iss $12 / 14$

Robie, D. (2002b). Freedom of speech in the Pacific: Don't shoot the messenger. Australian Journalism Review, 24(1), 147-153.

Robie, D. (2010). Pacific freedom of the press: Case studies in independent campusbased media models. Pacific Journalism Review, 16(2), 99-126. Retrieved from www. pjreview.info

Robie, D. (2012). Independent journalism in the South Pacific: Two campus-based media case studies in Fiji and New Zealand, Global Media Journal-Australian Edition, 6(1), 1-18.

Singh, S. (2010). Life under Decree No. 29 of 2010: The Fiji Media Development Decree. Pacific Journalism Review, 16(2), 147-162. Retrieved from www.pjreview.info

Smiles, S. (2001). Foreword. In Robie, D. (Ed.) The Pacific journalist: A practical guide (p. 32). Suva: University of the South Pacific.

Speaking of teaching: Problem based learning. (2001). Stanford University Newsletter on Teaching, 11(1), 2.

Swain, P. M. (1999). Civil society and development: Pacific Island case studies. Unpublished doctoral dissertation. Massey University, Palmerston North, New Zealand. Retrieved on May 10, 2016, from http://mro.massey.ac.nz/handle/10179/3949

Tuafuti, P. (2011). Multiple challenges in research within the fa'asamoa context. PacificAsian Education, 23(2), 33-42.

Tupuola, A. M. (1994). Raising research consciousness the fa'asamoa way. New Zealand Annual Review of Education, 3, 175-189.

USP probe over student chief attack on Wansolwara editor (2015, April 16). Pacific Media Watch 9219 FIJI. Retrieved from www.pmc.aut.ac.nz/pacific-media-watch/ fiji-usp-probe-over-student-chief-attack-wansolwara-editor-9219

USP students condemn 'highly reckless' police in PNG shootings (2016, June 10). Asia Pacific Report / Pacific Media Watch 9693 PNG. Retrieved from http://asiapacificreport. nz/2016/06/10/usp-student-journalists-condemn-highly-reckless-police-in-png-shootings/

Wake, A. (2016). Distant, disconnected and in danger: Are educators doing enough to prepare students for frontline freelance risks? Pacific Journalism Review: Endangered Journalists, 22(1), 52-73.

Wilkerson, L., \& Gijselaers, W. H. (1996). Concluding comments. In L. Wilkerson \& W. H. Gijselaers (Eds.), Bringing problem-based learning to higher education: Theory and practice (pp. 101-104). San Francisco: Jossey-Bass.

Wolfe, C. (2016, July). Online trolls and the freedom of speech: Devising a survival guide for journalism undergraduates and new entrants to the media industry. Paper presented at the 4th World Journalism Education Congress (WJEC), Auckland, Auckland University of the Technology, New Zealand. 
Dr Shailendra Singh is senior lecturer and the head of journalism at the University of the South Pacific in Suva, Fiji. He has widely covered Pacific media, politics and development, both as a journalist and as an academic. His major geographical area of research is the Pacific, with a focus on media development, conflict reporting and media policy.

shailendra.singh@usp.ac.fj

Eliki Drugunalevu is a postgraduate student in social policy and a teaching assistant in the journalism division, University of the South Pacific. He teaches the broadcast aspects of the course. His research interests are in media and social policy.

\section{JEANZ Jounalism Education Assocotition} of New Zealand Incorporated

JEANZ is the professional association of journalism educators and researchers in New Zealand. We invite all those interested in journalism teaching and research to join our organisation.

The membership fee includes a subscription to Pacific Journalism Review. The association runs an annual conference at journalism schools around the country and offers a scholarship to attend the conference of our Australian counterpart, JERAA.

For more details, please visit our website: jeanz.org.nz

To join up, click on "Jeanz membership benefits"

For the Australian scholarship, click on "Conference scholarships" 